\title{
AN EMPIRICAL INVESTIGATION OF E-GOVERNMENT ADOPTION IN RUSSIA: ACCESS, RIGHTS, TRUST AND CITIZENS' EXPERIENCE
}

\author{
Sergey A. Revyakin \\ Ph.D. (in Public Administration), Research Associate, \\ Center for Civil Society and Nonprofit Sector Studies, \\ National Research University Higher School of Economics \\ Address: 20 Myasnitskaya Str., 101000 Moscow, Russian Federation. \\ E-mail: sergey-revyakin@mail.ru
}

\section{Alvaro da Rocha}

Ph.D. (in Information Systems and Technologies), Professor, University of Coimbra (Portugal) and University of Lisbon; Honorary Professor, Amity University (India);

President of AISTI; Chair of IEEE SMC Portuguese Chapter.

Address: University of Coimbra, 3004-531 Paço das Escolas, Coimbra, Portugal.

E-mail: amrrocha@gmail.com

\begin{abstract}
The problem of low usage of e-government solutions is common in many emerging countries. Is Russia experiencing the same issue? Are there sufficient conditions to grow the usage of e-government solutions (internet penetration rate, rights for the citizens to approach the government remotely, trust in government, computer skills and usage perception, etc.)? Do the use rates for public e-services portals and e-participation platforms equal one another? Based on scholarly articles, analytical reports, laws, regulations, and the results of citizens' surveys, the research considers some factors that influence e-government implementation in Russia. The findings highlighted that the penetration of the Internet in Russia is high and that citizens have the right to approach the government remotely and trust the government. The survey demonstrated that the users believe they have enough knowledge and skills for using public e-services portals and e-participation platforms. At the same time, within the same institutional framework, the level of use of public e-services was still low in 2018 ( $29 \%$ of the respondents), and it was even lower for e-participation platforms ( $17 \%$ of the respondents). This observation suggests that the nature of e-government solutions (whether it is a public e-service portal or e-participation platform) should be considered when governments are developing roll-out programs.
\end{abstract}

Keywords: Internet penetration; e-government; public e-services; e-participation; trust; technology adoption. 
Citation: Revyakin, S. A. \& da Rocha, A. (2021). An Empirical Investigation of E-Government Adoption in Russia: Access, Rights, Trust and Citizens' Experience. Public Administration Issues, no 5 (Special Issue I, electronic edition), pp. 137-160 (in English). DOI: 10.17323/1999-5431-2021-0-5-137-160

\section{Introduction}

E-Government is a complex phenomenon (Scholl, 2002) and its implementation is usually associated with a more efficient and cost-effective delivery of public services, an increase in the transparency and accountability of government, better collaboration between the government, citizens and the businesses, etc. (see, for example, Dwivedi et al., (2017); Pedersen \& Tjørnehøj, (2018)). Initially, the simple definition of e-Government referred to the use of information and communication technologies (ICT) in government services to provide a better service for society (Sipior \& Ward, 2009; Yildiz, 2007). But over time, the concept of e-government has been developed toward citizens inclusion into government decision-making and it is also associated with three main opportunities for citizens: to get information from the government, to engage in electronic transactions to receive public services, and to participate in government decision-making (Bélanger \& Carter, 2008; Thompson et al., 2005).

All the developments in e-government are aimed at more efficient organization of government processes for citizens' convenience rather than the convenience of government agencies (Layne \& Lee, 2001), making public institutions more transparent and accountable (Pérez-Morote et al., 2020). It was made for the citizens to use it and to switch from traditional ways of contacting the government. However, the intensity of use of e-government solutions (platforms, portals) by citizens depends on many variables such as trust in the government (Bélanger \& Carter, 2008), psychological predispositions, civic-mindedness, information channels, and others (Dimitrova \& Chen, 2006). And despite the efforts, not all e-government projects are successful - some of them failed on adoption for different reasons (B. Q. J. Al Nidawy et al., 2018). And "despite the significant amounts of public investment devoted to enhancing e-government over the last ten years, citizens' use of this service is still limited, posing a challenge to national governments" (Pérez-Morote et al., 2020). Sipior and Ward (2009) defined three possible reasons: access to the Internet, computer skills, and e-government inclusion.

The study empirically investigates the context of the Russian Federation in recent years. In this article, we analyze some of the key factors that influence e-government adoption in Russia. Following Janssen, Sipior, and Thompson (Janssen \& Estevez, 2013; Sipior \& Ward, 2009; Thompson et al., 2005), we explore whether or not Internet penetration rate is high, whether citizens have the right to approach the government remotely. At the same time, we explore citizens' experiences with e-government tools by exploring the level of trust in government, the level of usage of public e-services portals and e-participation platforms, level of computer skills, and overall satisfaction. With this background, the current paper reviews scholarly articles, analytical reports, laws, and regu- 
lations to assess the development of public e-services and e-participation platforms and, based on surveys, to analyze citizens' experiences with e-government initiatives to answer the following research questions: What is the current level of use of e-government solutions in Russia (public e-services portals and e-participation platforms)? And is the use and satisfaction rate for public e-services portals and e-participation platforms equal within the same institutional framework within a country?

The remainder of the paper is organized as follows. The second section continues exploring the literature on the subject that shapes the model of further research and supports the research hypotheses. The latter is described in the third section. The fourth section describes the methodology of our research. And the fifth and sixth sections represent the results of the analysis. The ensuing discussion considers the theoretical and practical implications of this research. It also considers some directions for future research.

\section{Literature review}

The concept of e-government is broad and complicated. Janssen and Estevez (2013) discuss three main waves of the evolution of the implementation of information and communication technologies (ICT) into the public sector: e-Government, t-Government, and l-Government. During the first wave (e-Government) the technologies were implemented into public administration to improve public service delivery, to make it faster and easier. Online services were representing a web interface of the existing procedures in citizen-centric service provisioning with no radical changes to it (Front-end approach). Later, the technologies were used to increase the efficiency of public service provision (to transform bureaucracy) with radical organizational changes in the procedures at the same time ( $\mathrm{t}$-Government). The next wave (l-Government) was characterized by a reduction in government control and an increase in collaboration with citizens (delegation of power) aimed at doing more with less. Janssen and Estevez (ibid.) discuss that three waves are overlapping in time. Therefore, there are three main approaches to the implementation of ICT in public administration: Front-end approach (e-Government), Front-end + Back-end approach (t-Government), and Network manage \& orchestrate (l-Government). And each specific electronic service, portal, or platform could be set up using one of the above-mentioned approaches. Whatever it is, governments hope that their citizens will like it and use it.

The use of e-government solutions (platforms, portals) depends on many variables that could be divided into two groups. The first group of factors is under the governments' control. These are access to the Internet and e-government inclusion (Sipior \& Ward, 2009), security and privacy (Al-adawi et al., 2000; Carter \& Belanger, 2004b; Gil-garcia \& Pardo, 2006; Stephen H. et al., 2003), ICT infrastructure (wireless internet connections, computer centers, and kiosks) (Reffat, 2006), training support for citizens who find difficulty in using technology (ibid.), promotional events to improve people's awareness of the e-services provided and events to check progress (Al Bastaki, 2004; Missingham, 2013), 
and the right to access information, engage in electronic transactions with the government and to participate in government decision-making (Thompson et al., 2005), etc.

The second group of factors depends on the citizens. This group contains the variables such as appropriate level of computer skills and knowledge (Khalil et al., 2010; Sipior \& Ward, 2009), trust in the government (Bélanger \& Carter, 2008), perceived usefulness (PU), and perceived ease of use (PEOU) (Carter \& Belanger, 2004a; Lin et al., 2011; Warkentin et al., 2002), output quality and performance expectancy (Dwivedi et al., 2017), psychological predispositions, civic-mindedness, and information channels (Nam, 2014).

As we see from the literature review, many factors could potentially affect the usage. And its combination stipulates the actual level of adoption and usage in each specific country. In our article, we will choose the factors that we could assess within available sources of information and methodology. We will explore the level of internet penetration in Russia (to measure whether there is access), check the existence of citizens' rights to approach the government remotely, the level of trust in government, level of usage of public e-services portals and e-participation platforms, level of computer skills, and overall satisfaction.

\section{Hypothesis development}

Access to the internet is one of the key factors that affect the usage of e-government solutions (Sipior \& Ward, 2009). The countries that demonstrate high usage of e-government solutions have better access to the Internet (Al-adawi et al., 2000). Therefore, the first hypothesis in our research is derived from this statement:

H1: The penetration of the Internet in Russia is high (more than 70\%).

H1 acceptance criteria: if the penetration rate is any higher than $70 \%$.

To use e-government solutions, citizens have to get the rights to access information, engage in electronic transactions with the government, and participate in government decision-making (Thompson et al., 2005). Thus, the second hypothesis of our research is derived from this statement:

H2: Citizens' have the right to approach government authorities remotely.

H2 acceptance criteria: The rights of the citizens to approach government authorities remotely are regulated by law.

As was mentioned earlier, the usage of e-government tools (the demand for them) highly correlates with trust in the government (Bélanger \& Carter, 2008). The third hypothesis in our research is derived from this question:

H3: Citizens trust the Government of the Russian Federation

H3 acceptance criteria: positive response rate is higher than $50 \%$.

"The success of the e-government requires the usage of these electronic services by citizens" (B. Q. Al Nidawy et al., 2020). The fourth hypothesis in our research is derived from this statement:

H4: Citizens are ready to apply for public services online.

This broad-based hypothesis will be divided into more specific sub-hypotheses. To use e-portals, citizens should have the required knowledge and skills. 
And they shall believe in success in solving the issue when applying for public services online. Therefore, our H5.a and H5.b hypotheses are as follows:

H4.a. Citizens have enough knowledge and skills to use e-services portals.

H4.b. Usually, citizens find the application through e-services portals to be effective in solving their issues.

Having invested in e-government initiatives, governments hope their citizens will like the portals and be satisfied with them. Therefore, our H4.c hypothesis is as follows:

H4.c. Users like public-services portals and are satisfied with them; they are easy to use, work correctly and stably, and citizens have no worries when using them.

H4 acceptance criteria: all sub-hypotheses have been accepted. We will accept sub-hypotheses if the positive response rate is more than $50 \%$.

When testing this hypothesis, we will also explore the share of citizens who apply for public service online.

Along with public e-service delivery, e-participation is another dimension of the modern concept of e-government (Bélanger \& Carter, 2008; Thompson et al., 2005). Arranging the platforms for citizens to discuss and decide is quite a new and more complicated (advanced) form of e-government (Janowski et al., 2012; Janssen \& Estevez, 2013). Russia is one of the leading countries in the world in e-government development and e-participation (see section 5.2). But if the level of use for these two types of e-government solution is comparable in Russia - this is the focus of our fifth hypothesis.

H5: The level of use of public e-services portals and e-participation platforms is equal

H5 acceptance criteria: The use rate for public e-services portals and e-participation platforms is equal.

\section{Research approach}

This section highlights the data selected for the study, the methods, and the analytical approach adopted. This paper is a part of a more extensive research project $^{1}$ that focuses on the analysis of changes in public administration driven by digital technologies.

\subsection{Data selection}

We have chosen three types of data in line with our research question. We review scholarly articles, laws and regulations, surveys, and research reports (including reports from the analytical companies, European Commission, and the United Nations) to address our research question.

\subsection{Methods}

To find scholarly articles about the e-government concept, we ran a search in Scopus and ScienceDirect with search phrases such as (TITLE-ABS-KEY

\footnotetext{
1 Under the Basic Research Program at the National Research University Higher School of Economics
} 
(e-government)) AND (barrier) OR (challenge*) AND (legislation) or (TITLEABS-KEY (e-government AND adoption)) AND (rights). The search was made between September 2018 and June 2020. After that, we analyzed the results, narrowed them, and then ran a search among the results.

To explore Internet penetration (H1), we were looking for existing surveys and research reports. The search was conducted in Google and Yandex between September 2018 and June 2020 and was limited to trusted sources.

To define whether citizens have the right to approach the government remotely we analyzed laws and regulations in Russia. We ran a search on Government portals and regulatory databases which were adopted in 2002 when the federal target program 'Electronic Russia' was launched (see section 5.2). The search was made between September 2018 and June 2020.

To test hypotheses \#3-5, we used the survey data that the Center for Civil Society and Nonprofit Sector Studies of the National Research University Higher School of Economics collected in fall 2018.

\subsection{Analysis}

In line with our research question and the hypotheses, we performed desk research and the survey. At first, we carried out the desk research to learn about Internet penetration in Russia (H1) and the rights of the citizens (H2). We used the data from GFK survey reports exploring Internet penetration rates in 20082018, considering the structure in age groups and the main reasons why it is not used in Russia. We analyzed the regulation in Russia to define the extended rights of citizens to contact the government electronically. Existing public e-services portals and e-participation platforms were explored as part of the e-government landscape.

In the fall of 2018, we conducted an All-Russian population survey of adults (age 18+) on a representative sample (gender, age, education, type of settlement) to test hypotheses \#3-7. A total of 2049 respondents participated in a face-to-face survey with a flexible, conversational interview format in 48 regions of the Russian Federation. The average age of the respondents is 44 , the asymmetry is positive $(0,197)$ and it is within the ranges $(-1$ to 1$)$, therefore, the distribution over this variable can be considered as normal, and we have bimodal age distribution (Fig. 1). The excess is negative but does not exceed 1 in absolute value, which proves the normality of the distribution.

Women prevail in survey gender structure (Fig. 2).

The respondents with higher education have roughly $23 \%$ of the share, while respondents with secondary education (general and specialized) have the biggest share among the respondents (57.5\%) (Fig. 3).

The questionnaire contained 29 questions on citizens' experiences with both offline and online interactions with government authorities, although only a portion of the questions relates to the topic of this article ${ }^{2}$.

\footnotetext{
2 This paper is a part of a more extensive research project that focuses on the analysis of changes in public administration driven by digital technologies (under the Basic Research Program at the National Research University Higher School of Economics).
} 


\section{Figure 1: Age Distribution of Survey Respondents (HSE All-Russian population survey 18+, 2018).}

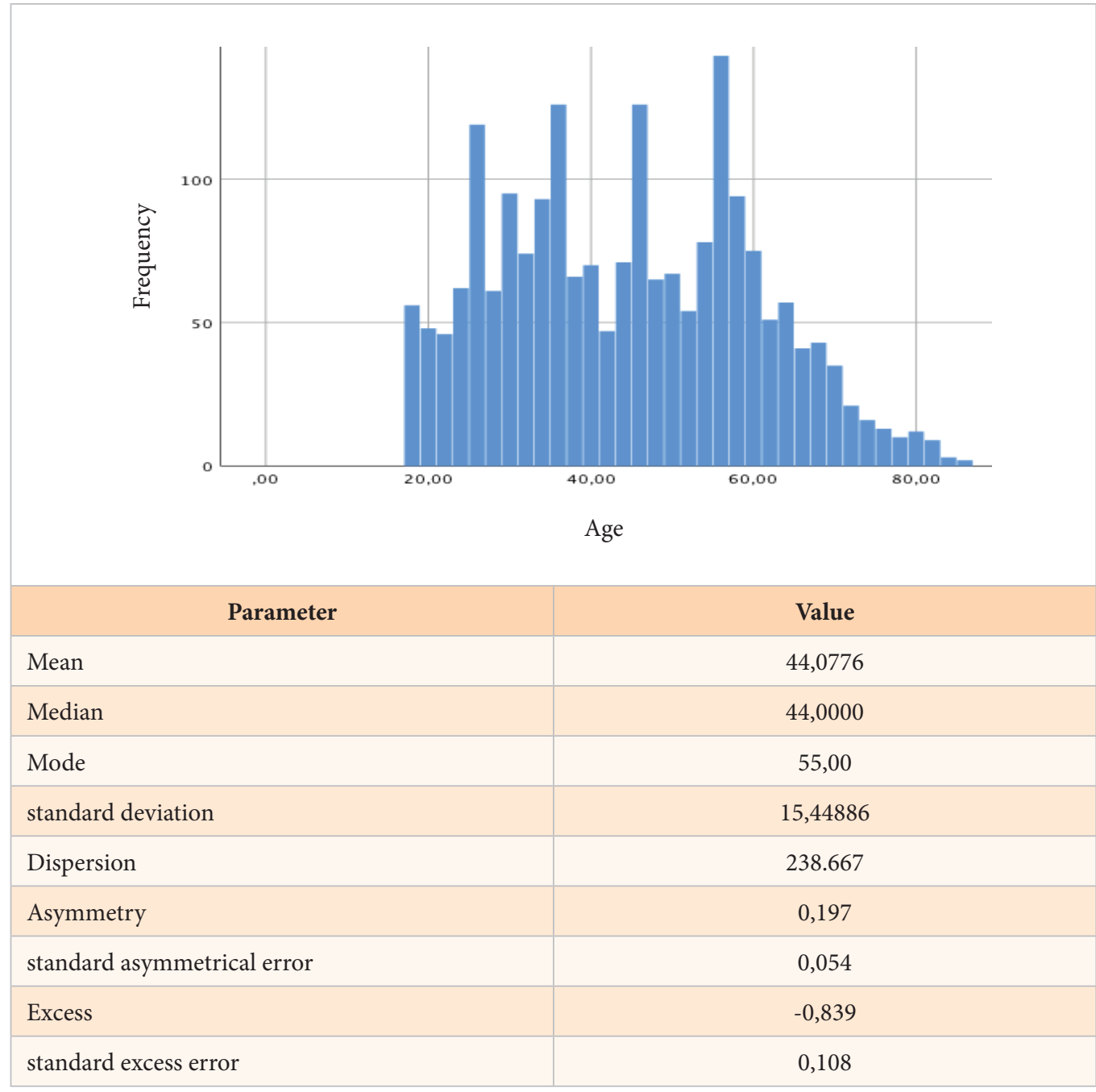

Figure 2: Gender Distribution of Survey Respondents (HSE All-Russian population survey 18+, 2018).

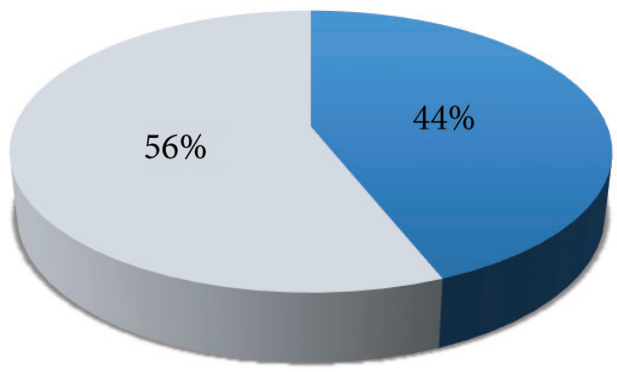

Male Female 


\section{Figure 3: Education structure of the survey (HSE All-Russian population survey 18+, 2018).}

\begin{tabular}{|c|c|}
\hline Incomplete secondary or lower & $9,8 \%$ \\
\hline Secondary general (school) & $24,7 \%$ \\
\hline Primary professional (vocational school,... & $5,8 \%$ \\
\hline Special secondary (college, technical... & $32,8 \%$ \\
\hline Incomplete higher education (studied... & $3,9 \%$ \\
\hline Higher (specialist diploma, bachelor,... & $22,5 \%$ \\
\hline Graduate School, Degree, Title & \\
\hline Hard to answer & \\
\hline
\end{tabular}

5. E-government in Russia: access to the Internet and citizens' rights

\subsection{Internet penetration in Russia}

The penetration of the Internet was increasing all over Russia between 20142018. In $2018,75.4 \%$ of citizens in Russia had access $\left(76 \%{ }^{3}-79.8 \%{ }^{4}\right.$ in $2019-$ which is comparable to Latin America/Caribbean countries (70.5\%), but lower than in Europe (87.2\%) and North America (94.6\%)) (Fig. 4).

\section{Figure 4: Penetration of the Internet in Russia (2008-2018)} (Omnibus GFK-Rus, the whole of Russia, population 16+) ${ }^{6}$

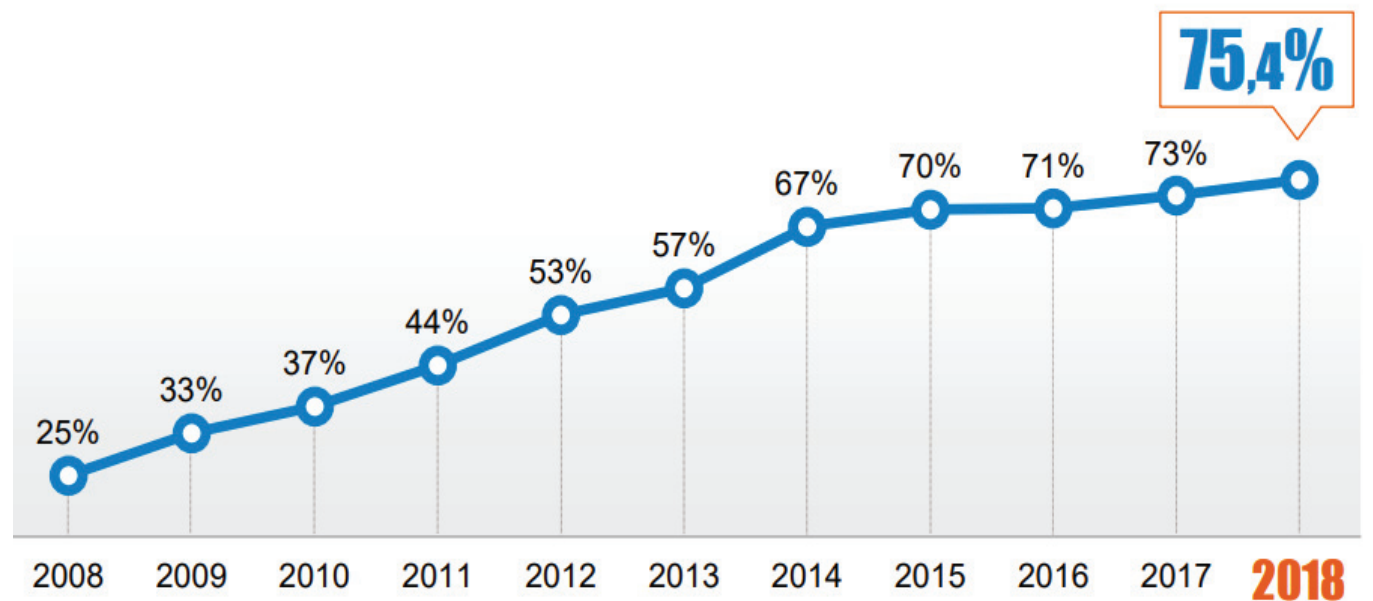

\footnotetext{
3 URL: https://mediascope.net/news/1035826 (last access: 29.04.2021).https://mediascope.net/news/1035826/

4 URL: https://www.gfk.com/ru/press/issledovanie-kazhdyi-pjatyi-vzroslyi-rossijanin-ne-polzuetsja-internetom ?hsLang=ru / (last access: 29.04.2021).

5 URL: https://www.internetworldstats.com/stats.htm (last access: 29.04.2021).

6 URL: https://www.gfk.com/fileadmin/user_upload/dyna_content/RU/Documents/Press_Releases/2019/GfK_ Rus_Internet_Audience_in_Russia_2018.pdf (last access: 29.04.2021).
} 
After a dramatic increase in 2013, the growth rate is slowly decreasing. Further growth is mostly expected from involving elderly people to use the Internet, while among young and middle-aged people Internet penetration is close to the limit (Fig. 5). In addition, $61 \%$ of the population is using mobile Internet, and smartphones are preferable to tablets ${ }^{7}$.

\section{Figure 5: Internet penetration in age groups}

\section{(Omnibus GFK-Rus, the whole of Russia, population 16+) ${ }^{8}$.}
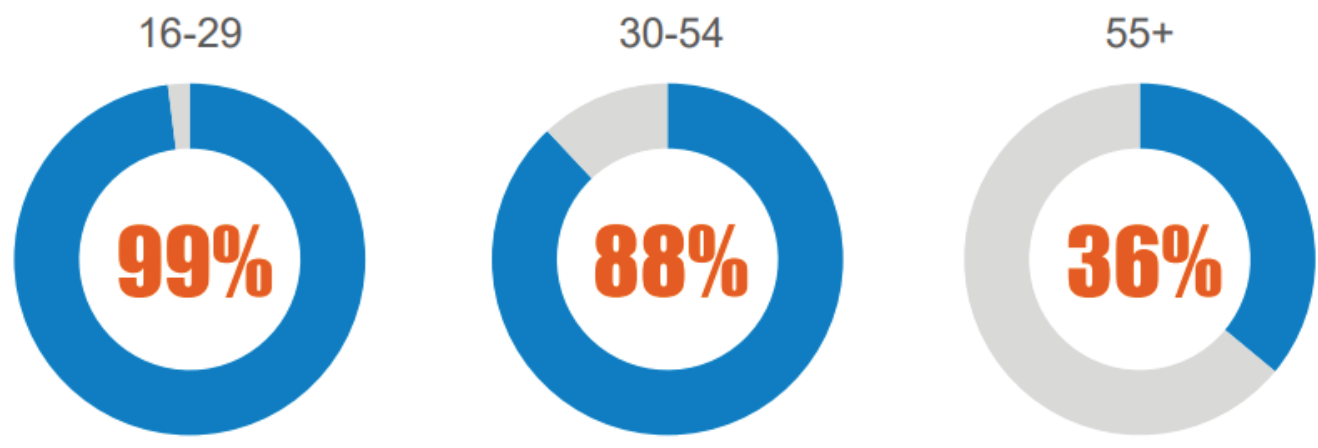

Of the total Russian population, $20.2 \%{ }^{9}$ (more than 24 million people) do not use the Internet. The main reasons are the following: there is no need (55\% in 2018 and $48.4 \%$ in $2019^{10}$ ), lack of skills (29.1\% in 2018, 35.7\% in 2019), and absence of a device - computer, laptop or smartphone (Fig. 6).

\section{Figure 6: Why 24 mln citizens do not use the Internet} (GfK All-Russian Representative Survey, 16+, 2019) ${ }^{11}$.
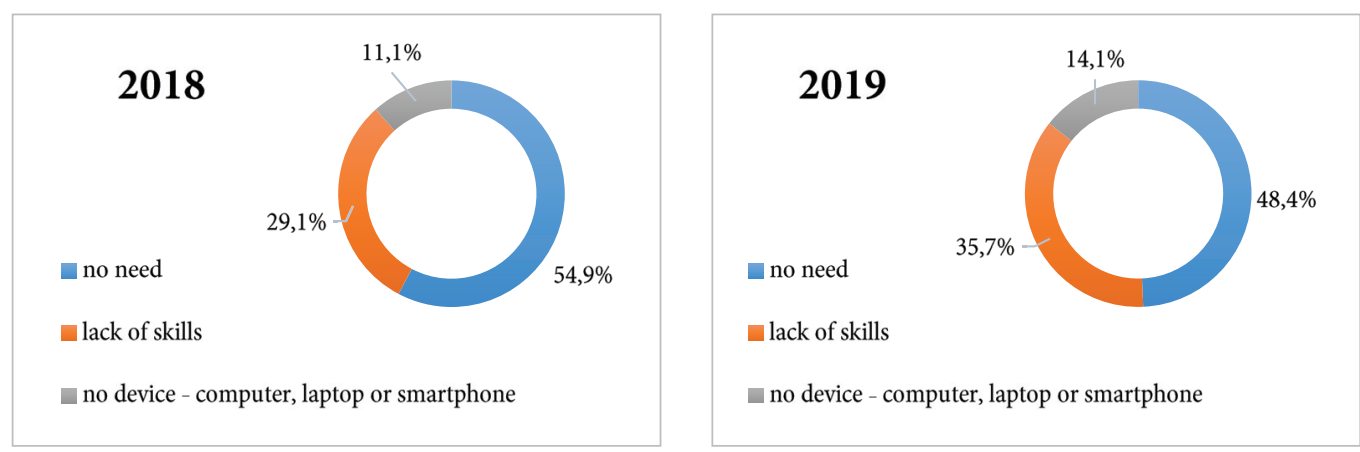

\footnotetext{
7 URL: https://www.gfk.com/fileadmin/user_upload/dyna_content/RU/Documents/Press_Releases/2019/GfK_ Rus_Internet_Audience_in_Russia_2018.pdf (last access: 29.04.2021).

8 URL: ibid.

9 URL: https://www.gfk.com/ru/press/issledovanie-kazhdyi-pjatyi-vzroslyi-rossijanin-ne-polzuetsja-internetom ?hsLang=ru / (last access: 29.04.2021).

${ }^{10}$ Of all who does not use Internet.

${ }^{11}$ URL: https://www.gfk.com/ru/press/issledovanie-kazhdyi-pjatyi-vzroslyi-rossijanin-ne-polzuetsja-internetom ?hsLang=ru / (last access: 29.04.2021).
} 
As we can see from the dynamics (Fig.6), the share of people who "do not need" the Internet is decreasing. It seems that they acknowledge the need and have found that they do not have proper devices and skills (both "no device" and "lack of skills" shares are increasing).

As per the concept of our study and the results described in section 4.1 (Fig. 4), we shall accept the first hypothesis (H1: The penetration of the Internet in Russia is high (more than 70\%)).

\subsection{E-government in Russia: the rights of the citizens}

The Russian Federation is one of the leading countries in e-government development and e-participation (32nd place in the list of the top-ranking countries, 23rd place in the E-Participation Index (EPI) according to the United Nations 2018 Survey) (United Nations, 2018). The importance of the e-government concept has been officially recognized in Russia since 2002.

The institutional foundations for the penetration of electronic technologies in public administration in Russia were laid in 2002-2010 by implementing the federal target program (Electronic Russia).

The goal of the program was to improve the quality of interactions between the government and society by providing citizens with the right to access information about the activities of public authorities by increasing the efficiency of public e-services delivery, including the introduction of uniform standards for serving citizens $^{12}$.

Since 2006 citizens have been eligible to contact government authorities electronically (Article 2 of the Federal Law of 27.07.2006 №149-FZ “On Information, Information Technologies and the Protection of Information"13).

In 2009, the Russian Government launched the Federal public e-services portal "Gosuslugi"14. In Janssen's classification, ${ }^{15}$ it is a T-government model aimed at increasing the efficiency of public e-service delivery by implementing innovative IT solutions along with radical organizational changes. Before the service was implemented, citizens had to approach a government body in person (with a few exceptions).

Since its launch, many government services have been available online through the one-window portal which should decrease the transactional cost for citizens per service obtained. In Multifunctional Centers that the government has established throughout cities, citizens are involved in changing the way they communicate with the government. Along with the Federal public e-services portal "Gosuslugi," there are Regional portals of state and municipal services.

Besides public e-services portals, there is an additional type of portal focused on the collection of citizens' complaints on the quality of public services and/or

\footnotetext{
${ }_{12}$ URL: https://digital.gov.ru/ru/activity/programs/6/ (last access: 29.04.2021).

${ }^{13}$ URL: http://www.consultant.ru/document/cons_doc_LAW_61798/(last access: 29.04.2021).

${ }^{14}$ URL: https://www.gosuslugi.ru/ (last access: 29.04.2021).

${ }^{15}$ We will not consider the earlier stage of implementation of e-services - when government authorities launched their websites.
} 
ideas on their improvement. For instance, the portal of the Government of Moscow "Our City"16 allows any issue on Housing and Utilities to be submitted, and the "Russian public initiative" 17 allows the publication of public petitions to be considered by the government if they collect enough public votes.

In recent years there has been an increase in the number of e-participation portals that allow citizens to participate in the government decision-making process. For example, one of the most advanced e-participation platforms in Russia is "Activny grazhdanin" (Active citizen) launched by the Moscow authorities. This platform is the winner of awards such as the Smart Cities Awards-2015 ${ }^{18}$. Established in 2014, the platform was aimed at obtaining the opinion of Muscovites on pressing issues related to the development of Moscow. This platform showed reliability, the integrity of voting results, and the lack of the ability to manipulate the vote $\left(\mathrm{PWC}^{19}\right)$.

Therefore, along with the implementation of e-government initiatives in Russia, citizens gained the right to approach government authorities remotely (electronically).

As per the concept of our study and the results of section 5.2, we shall accept the second hypothesis (H2: Citizens' have the right to approach government authorities remotely.

\subsection{Trust in Government institutions}

To explore the output of Government efforts we performed the survey using the methodology described in section 4.

From the survey, we learned that the trust rate ${ }^{20}$ is a bit higher than $50 \%$ for the Government of the Russian Federation (50,1\%). (Fig. 7).

\section{Figure 7: Question: Do you or do you not trust to...? (HSE All-Russian population survey 18+, 2018).}

\section{The Government of the Russian Federation}

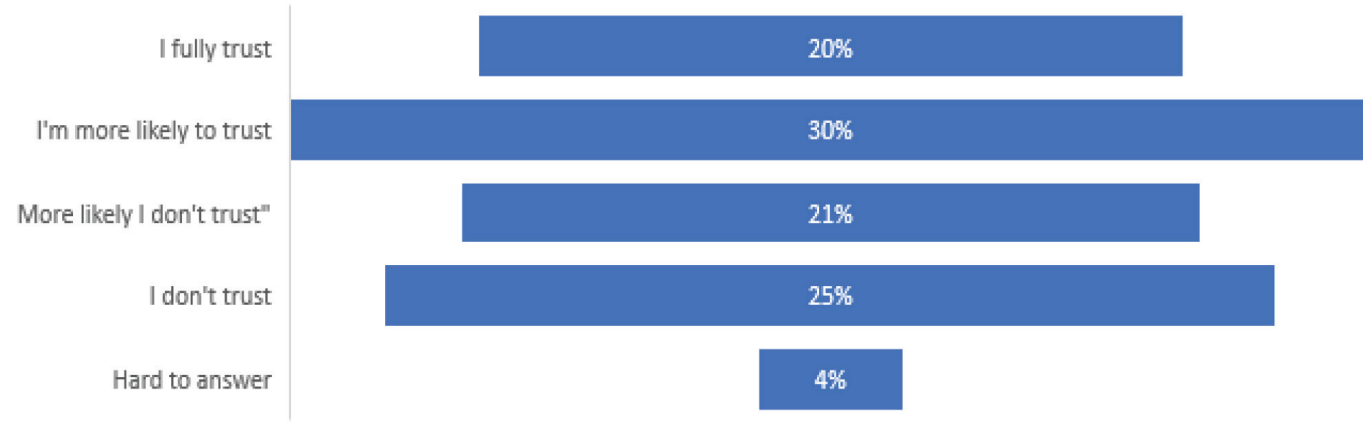

\footnotetext{
${ }^{16}$ URL: https://gorod.mos.ru/ (last access: 29.04.2021).

${ }_{17}$ URL: https://www.roi.ru/page/about/ (last access: 29.04.2021).

${ }_{18}$ URL: https://ag.mos.ru/blockchain (last access: 29.04.2021).

${ }^{19}$ URL: https://ag.mos.ru/news/936 (last access: 29.04.2021).

${ }^{20}$ As the sum of the shares of those who "fully trust" and "more likely to trust".
} 
As per the concept of our study and the results of section 5.3, we shall accept the third hypothesis (H3: Citizens trust the Government of the Russian Federation). Note that the trust level has a borderline value in comparison to the condition of acceptance of this hypothesis.

\section{Public e-services and e-participation}

\subsection{Citizens' experience with public e-services portals}

In $2018^{21}, 74 \%$ of the population applied for public services offline (Tab. 1).

Table 1

\section{Question: Which of these institutions did you address last year? (\% of the total sample.).}

\begin{tabular}{|l|c|}
\hline MFC (My Documents Multifunctional Center) & 47 \\
\hline Pension Fund & 24 \\
\hline Tax Authority & 21 \\
\hline Social Security Agencies & 9 \\
\hline Registry office & 9 \\
\hline Registration (or Cadastral) Office & 6 \\
\hline Employment Service & 6 \\
\hline Social Insurance Fund & 4 \\
\hline Federal Migration Service & 4 \\
\hline I have not addressed any of them & 25 \\
\hline Difficult to answer & 1 \\
\hline
\end{tabular}

Sourse: HSE All-Russian population survey 18+, 2018.

Almost one in three citizens (29\%) received any public services electronically (using a computer or smartphone). But over the past few years, after almost triple growth in $2015-2016$ (from $11 \%$ in $2013^{22}$ to $29 \%$ in $2016^{23}$ ), this indicator has stabilized at $29 \%$ and the growth is yet to come if it is to be considered a high level of Internet penetration in Russia $\left(79,8 \%{ }^{24}\right)$.

The survey showed that citizens have enough knowledge and skills on how to use public e-services portals - $81 \%$ of users are highly aware of the possibilities of the portals (Fig. 8) and $84 \%$ confirmed they have enough skills to use portals (Fig. 9).

\footnotetext{
${ }^{21}$ Survey performed in Autumn, 2018.

${ }^{22}$ URL: http://www.gks.ru/free_doc/new_site/business/it/fed_nabl/t5-1.xlsx (last access: 29.04.2021).

${ }^{23}$ URL: https://rosstat.gov.ru/free_doc/new_site/business/it/fed_nabl-croc/PublishData/Reports/Files/2016/ 5.1.xlsx (last access: 19.03.2021).

${ }^{24}$ URL: https://www.gfk.com/ru/press/issledovanie-kazhdyi-pjatyi-vzroslyi-rossijanin-ne-polzuetsja-internetom ?hsLang=ru / (last access: 29.04.2021).
} 
Figure 8: Question: How would you rate your knowledge about the possibilities of using public e-services portals of state and municipal services? (HSE All-Russian population survey 18+, 2018).

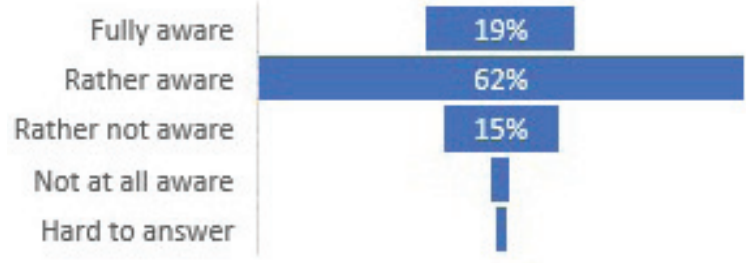

Figure 9: Question: How would you rate your level as a user of public e-services portals of state and municipal services? (HSE All-Russian population survey 18+, 2018).

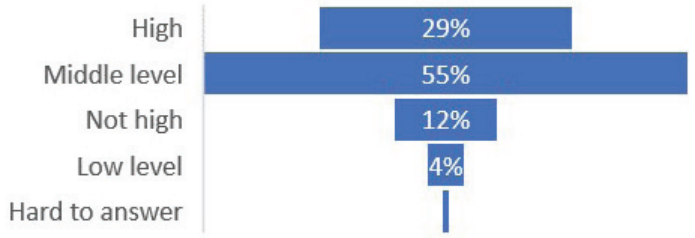

At least half of all users of public e-services (53\%) found it to be effective in solving their issues (Fig. 10).

Figure 10: Question: How often have you managed to resolve your issues when using the portals of state and municipal services? (HSE All-Russian population survey 18+, 2018).

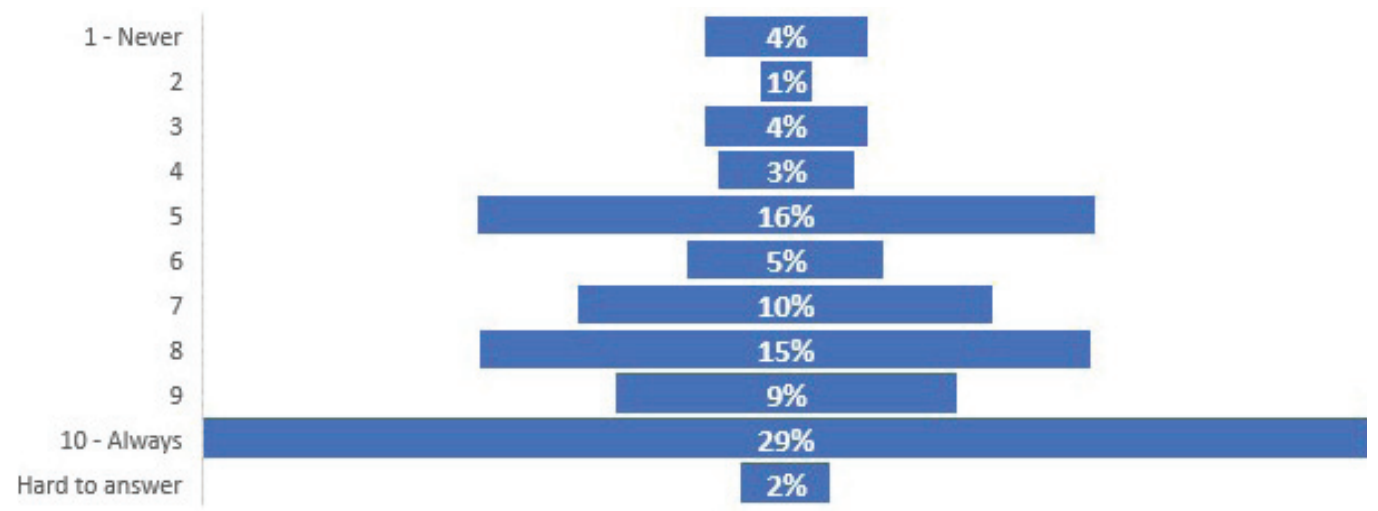

The overall satisfaction rate of users of public e-services portals (at federal and municipal level) is very high (88\%) (Fig. 10) and is similar to the satisfaction rate with public services obtained offline (84\%).

The most popular e-service platform in Russia is the federal portal Gosuslugi.ru - at least two-thirds of users of public e-services (69\%) used it when applying for the service (Fig. 11). Every fifth user turned to the regional portal of state and municipal services (21\%). Despite this, the satisfaction rate does not differ significantly among the portals (federal or municipal) and did not fall below 67\% (Fig. 11). 
Figure 11: Question: Please choose the portal of state or municipal services you remember the most. (HSE All-Russian population survey 18+, 2018).

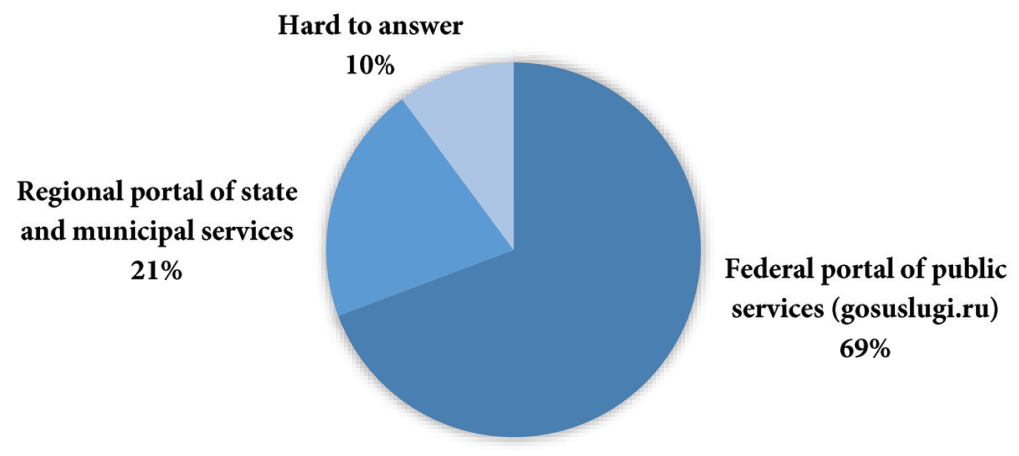

Users like public-services portals and are satisfied with using them, meanwhile there is room for improvement (for instance, 19\% of citizens faced stability issues at the portals) (Fig. 12).

Figure 12: Questions: In general, I like the portal (Q1). Are you satisfied with the use of the portal? (Q2). It is easy to use the portal? (Q3) Does the portal work correctly and stably? (Q4). I'm not afraid to use the portal (Q5). (HSE All-Russian population survey 18+, 2018).

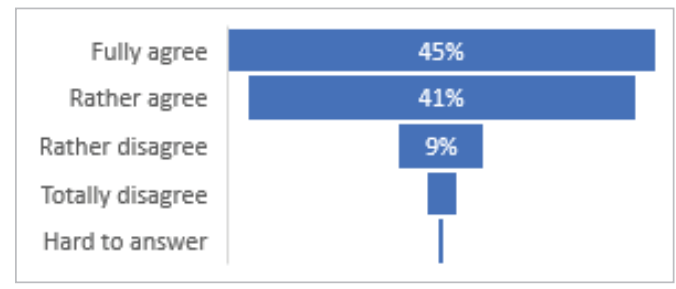

Quadrant 1

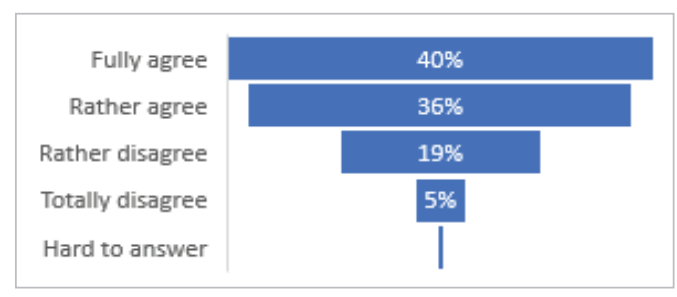

Quadrant 3

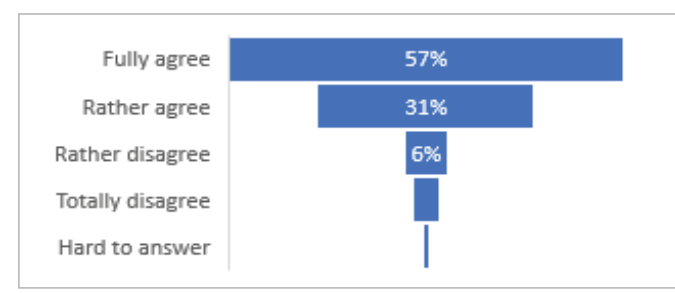

Quadrant 5

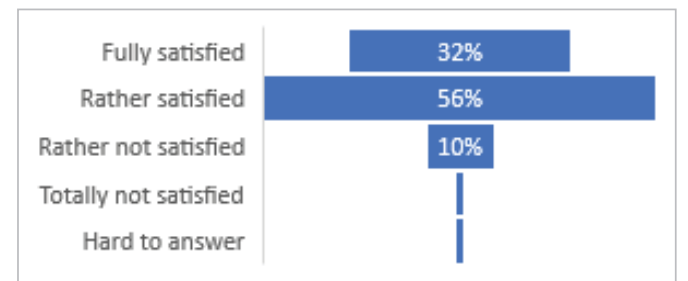

Quadrant 2

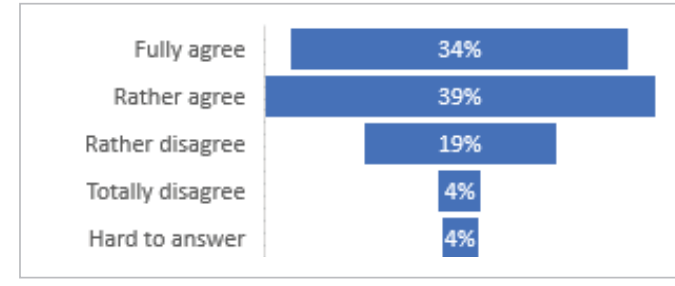

Quadrant 4 
These rates are higher for the federal portal in comparison to regional portals (for example, on reliability and safety).

In section 6.1 we learned that 29\% of the population in Russia applies for public services electronically. Current users believe they have enough knowledge and skills to apply for public e-services. But only half of them found the use of portals to be effective in solving the issue. Nevertheless, the satisfaction rate of the portals is high and people like the portals but emphasize that they could be improved, for instance in terms of stability of operations. Thus, citizens were satisfied and able to obtain the desired result when applying for public services online - although the share of citizens remains low and most of the people are used to applying for public services traditionally.

As per the concept of our study and the results of section 6.1, we shall accept the fourth hypothesis (H4: Citizens are ready to apply for public services online) as soon as we have accepted all sub-hypotheses.

\subsection{Citizens' experience with e-participation platforms ${ }^{25}$}

$33 \%$ of the citizens in Russia believe in the value of using the platforms, while $23 \%$ of citizens could not estimate the value (Fig. 13).

\section{Figure 13: Question: Are various interactive and electronic portals effective tools for influencing environmental changes, observing citizens' rights, and developing socially significant projects in various fields? (HSE All-Russian population survey 18+, 2018).}

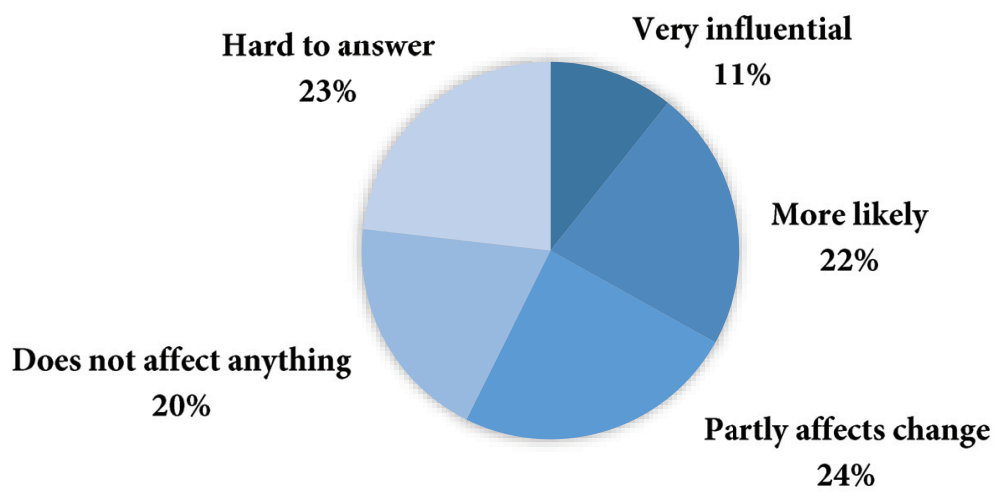

It seems that this $23 \%$ are potential active users if provided with additional information and the incentives to participate are demonstrated.

At the same time, only $17 \%$ of citizens have tried e-participation platforms. Most citizens $(81 \%)$ do not use this type of interaction with the government (Fig. 14).

\footnotetext{
${ }^{25}$ We will use separate terms for e-participation websites in order to separate it from public e-service portals. Saying a platform, we will mean communication capabilities inside.
} 
Figure 14: Have you used e-participation platforms in the last 2-3 years to solve your or others' problems or questions? (HSE All-Russian population survey 18+, 2018).

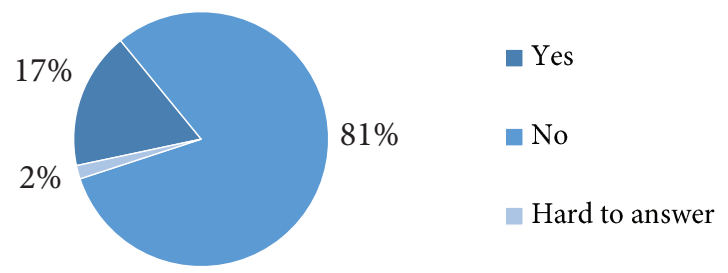

Most of the users are satisfied with their experience with e-participation platforms. Key user characteristics - reliability and functionality, - fully meet the requirements of citizens (Fig. 15).

Figure 15: Statement/Questions: Using the e-platforms is quick and easy $(\mathrm{Q} 1)$. E-participation platforms work correctly and stably (Q2). The electronic portal can be considered reliable (Q3). I understand how

to file a query (Q4). I am a professional user of such a portal (Q5).

I am not afraid to use e-platforms (Q6). Are you satisfied with your experience with the platform? (Q7). In general, I like e-platforms (Q8).

(HSE All-Russian population survey 18+, 2018).

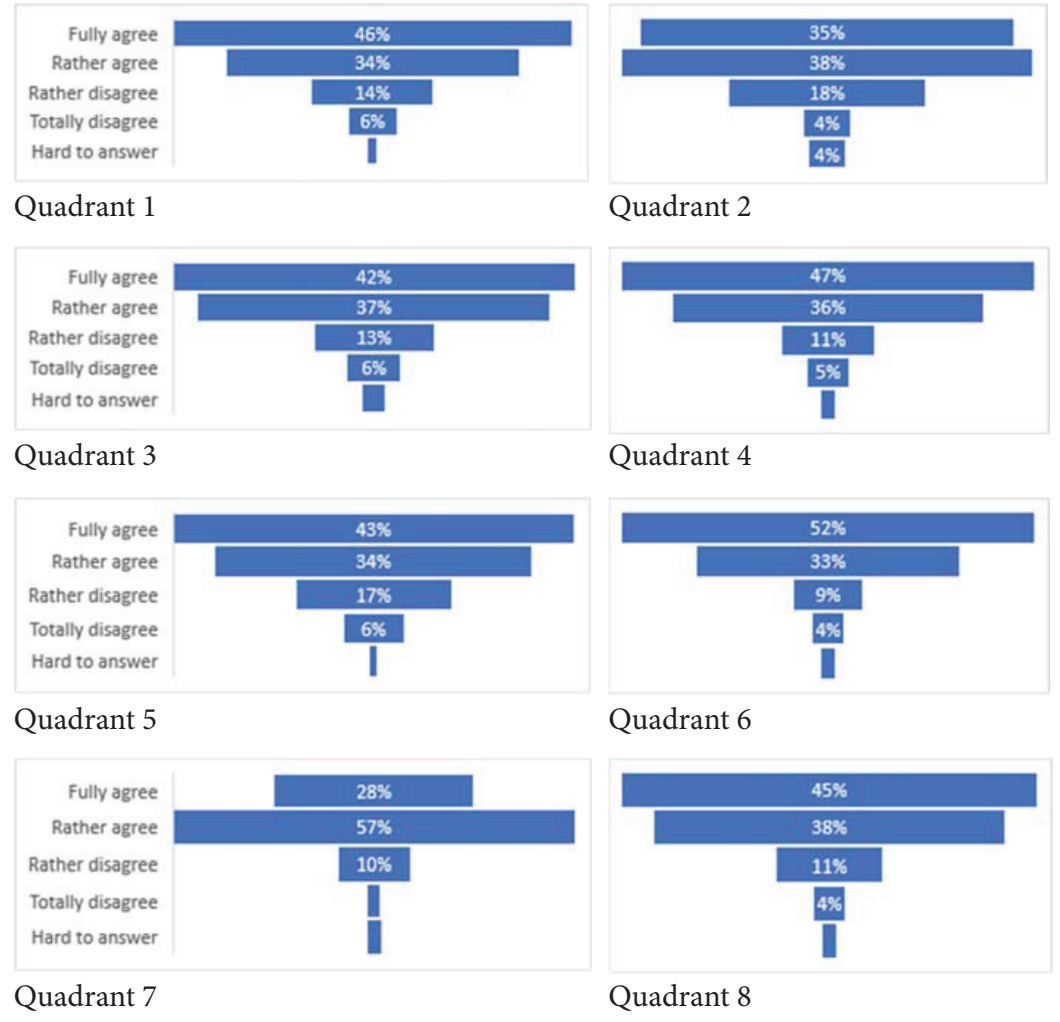

Being satisfied with the experience at the platform, citizens believe that in the future the use of the e-participation platforms will increase (Fig. 16). 


\section{Figure 16: Question: How the frequency of use of e-platforms will} change in the future? (HSE All-Russian population survey 18+, 2018).

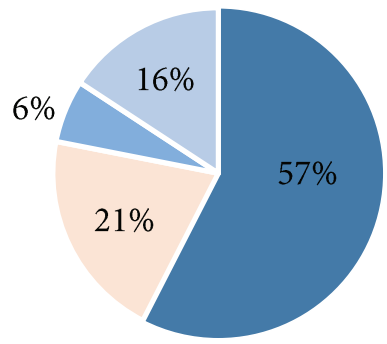

Will use more often

Not much will change

Will use less frequently

Hard to answer

In section 6.2 we learned that one-third of citizens believe in the value of e-participation platforms, and 20\% of citizens believe that it does not affect anything, but only $17 \%$ of citizens use it. Users are satisfied with the platforms and believe that in the future the use of them will increase.

However, the penetration rate of the e-participation platform is low.

As we see from the analysis, the use rate for public e-services portals and e-participation platforms is not equal (29\% vs. $17 \%)$. At the same time, the satisfaction rates and the perception of use do not differ significantly.

As per the concept of our study and the results of section 6.2, we shall reject the fifth hypothesis (H5. The level of use of public e-services portals and e-participation platforms is equal).

\section{Discussion}

Considering the results of our study we did not accept all the hypotheses (Tab. 2).

Table 2

\section{H1-H5 test results}

\begin{tabular}{|l|l|}
\hline \multicolumn{1}{|c|}{ Hypotheses } & \multicolumn{1}{|c|}{ Results } \\
\hline H1: The penetration of the Internet in Russia is high (more than 70\%). & Acceptance $(+)$ \\
\hline H2: Citizens have the right to approach government authorities remotely. & Acceptance $(+)$ \\
\hline H3: Citizens trust the Government of the Russian Federation. & Acceptance $(+)$ \\
\hline H4: Citizens are ready to apply for public services online. & Acceptance $(+)$ \\
\hline $\begin{array}{l}\text { H4.a: Citizens have enough knowledge and skills to use e-services portals. } \\
\text { H4.b: Usually citizens find application through e-services portals to be effective } \\
\text { in solving their issues. }\end{array}$ & Acceptance $(+)$ \\
\hline $\begin{array}{l}\text { H4.c: Users like public-services portals and are satisfied with them, it is easy } \\
\text { to use, it works correctly and stably, and citizens have no worries about using it. }\end{array}$ & Acceptance $(+)$ \\
\hline \begin{tabular}{l} 
H5: The level of use of public e-services portals and e-participation platforms is equal. \\
\hline
\end{tabular} & Rejection $(-)$ \\
\hline
\end{tabular}

Sources: Compiled by the authors. 
As we learned from section 5.1, the penetration rate of the Internet is rather high (79,8\% ${ }^{26}$ in 2019). We accepted H1 (Tab. 2) and confirmed that $79.8 \%$ of citizens have access to the Internet, which is one of the key conditions for the high usage of e-government solutions (Sipior \& Ward, 2009). But the growth rate has been decreasing since 2013, which means that the growth potential is close to its limit within the current institutional framework. Along with further institutional developments, the growth might be sourced from encouraging the elderly (the penetration rate is 36\%) and middle-aged people (the penetration rate is $88 \%$ ) to use the Internet.

As we learned from section 5.2, the Russian government is developing public e-services portals and e-participation platforms along with extending citizens' rights $(\mathrm{H} 2)$. Along with high Internet penetration, this is another factor that shall stipulate high usage of e-government tools.

However, we revealed a usage gap between public e-services portals and e-participation platforms. In our research, only $29 \%$ of citizens reported using the Internet for obtaining public services, and $17 \%$ of such citizens used public participation platforms (Fig. 17). This gap in Russia is not unique and other governments all around the world have experienced the same. When Bélanger was describing the experience of the US Government in implementing e-government initiatives he mentioned that "despite the governments' growing investment in electronic services, citizens are still more likely to use traditional methods, e.g., phone calls or in-person visits, than the Web to interact with the government" (Bélanger \& Carter, 2008).

\section{Figure 17. The demand chain (the level of penetration, penetration rate, 2018) (HSE All-Russian population survey 18+, 2018).}

Demand for public services obtained in a traditional way

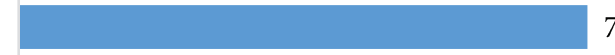

Demand for public services obtained electronically $29 \%$

Demand for public e-participation $17 \%$ $0 \%$ $20 \%$ $40 \%$

$60 \%$ $80 \%$

Taking into consideration the high demand for public services and the high Internet penetration rate (Fig. 17), the current level of adoption of e-government initiatives in Russia seems to be low in comparison to other countries. For instance, in European countries, 57\% of individuals aged 16 to 74 reported using the Internet for interaction with public authorities in 2018 (European Commission, 2018) which is also considered to be low (Pérez-Morote et al., 2020). At the same

\footnotetext{
${ }^{26}$ URL: https://www.gfk.com/ru/press/issledovanie-kazhdyi-pjatyi-vzroslyi-rossijanin-ne-polzuetsja-internetom ?hsLang=ru / (last access: 29.04.2021).
} 
time, usage phenomena shall be explored additionally soon; "measuring usage is challenging and obtaining pertinent data is much more difficult than measuring the supply side of e-government functions" (Nam, 2014).

The absence of need, a lack of skills, and the absence of devices were named as the main reasons why citizens did not use the Internet in 2018-2019. It might also be the reason why the high demand for public services is not converting into high demand for public e-services (which is associated with ease and efficiency) when the penetration of the Internet is high. But this statement needs to be further explored and proved. If it is proved to increase Internet and public e-services penetration rate further, we might suggest focusing on the advertising of success stories in using public e-services, on education support for the elderly and others, on special discount programs to purchase (or rent) a device, or on increasing the awareness about public computer rooms that are available at Multifunctional Centers for public services.

Another reason for the low usage that is mentioned in the literature is a lack of trust in the government (B. Q. J. Al Nidawy et al., 2018). As we learned from section 5.3, we accepted $\mathrm{H} 3$, but the value of the indicator is close to the one that has to be rejected.

The current level of trust in the government is quite moderate $(50,1 \%)$. As soon as we know from the literature that a low level of trust negatively affects the usage, the current level in Russia could also negatively affect the usage of egovernment tools and explain why there is a significant gap between the usage rate of the public services obtained traditionally (74\%) and online (29\%).

"Many citizens may be reluctant to adopt e-government services due to a lack of trust in the security of online transactions and concerns regarding the use of information submited electronically" (Bélanger \& Carter, 2008), and both trust in the Internet and trust in the government matters when considering the intensity of use of e-government tools. But the high penetration rate of the Internet in Russia could be interpreted as a trust in technology. Perhaps one of the reasons for the low level of demand for e-government tools is the lack of trust in this specific technology (not trust in the Internet but trust in privacy, accuracy, the security of personal data transfer when submitting the application and the unknown price of the error). And as we learned from Figure 13, citizens who tried public e-services portals believe that it works accurately, stable, and secures privacy, and ranged their experience to be positive and successful. Therefore, the first experience matters and one of the further government efforts towards usage increase could be the development of the measures for citizens to make the first attempt with public e-services and make sure it is successful. Sipior et al. advised: "to secure Internet access, coordinate education and training, and sustain Internet use to initiate e-Government participation among the techno-disadvantaged" (Sipior \& Ward, 2009). To motivate citizens to have their first attempt the government could use social advertising (sharing successful experiences) through interpersonal channels (e.g., from friends, family, coworkers) and mass media channels (Dimitrova \& Chen, 2006), provide extended online and offline support for users, and launch of educational programs, etc. 
We revealed that demand for public e-services in Russia is not so high, but it is even lower for public participation platforms (Fig. 17). It seems that some additional factors affect usage in comparison to those which negatively affect the use of public e-service. These factors might not work for public e-services, as soon as there is an obvious need to get something (sometimes it is a must to register at the portals to get public services offline, or an offline service is not available anymore), while there is no need or obligations to participate, hence there should be some other motivation to get involved. And that could be the explanation of why the penetration of public e-services is almost two times higher than for e-participation. Therefore, our hypothesis for further research is the following:

A lack of trust, skills, needs, devices and first successful experience negatively affect the demand (usage) for public e-services, but it affects e-participation to a higher extent within the same institutional framework. Therefore, from a theoretical and practical perspective, the nature of e-government solutions should be considered when governments are developing roll-out programs. To grow usage of e-participation, there should be a growth in usage of public e-services (to be involved by e-government technology), having obtained a positive first-time experience that was broadly shared via two main informational channels (interpersonal channels and mass media channels).

The research undertaken produced three practical recommendations to accelerate the usage of e-government solutions:

1. To increase the Internet penetration rate in Russia in the 30-54 and 55+ age groups, and to develop measures to increase trust in the government.

2. Empower the first successful experience of the citizens (who currently do not use it) by sharing success stories ("no-need" issue, "trust in e-government technology" issue), educational arrangements (incl. for elderly people), and increasing the awareness about public computer rooms that are available at Multifunctional Centers for public services ("no-skills" issue) and special discount programs (subsidies) to purchase (rent) a device ("no-device" issue).

3. Analyze the factors that affect the usage of e-participation in Russia (as soon as the level of usage of it differs from the same level for public e-services portals). Develop separate strategies for growth in usage of public e-services and e-participation platforms.

Today e-government can be considered as one of the multiple options that citizens can select for their interactions with the government (Nam, 2014). And as soon as this is a relatively new option, maybe the government shall not worry about the lower usage (in comparison to traditional channels of interaction) and consider it to be evolutional? "The increase in citizens' use of e-government, nevertheless, becomes a discernible long-term trend because a growing number of people have recognized and experienced greater efficiency, effectiveness, and convenience in using various government functions via e-government and digital connections with conventional channels" (Nam, 2014). It seems that the process of the implementation of technology into public administration takes time and the progress depends on many factors that may differ significantly be- 
tween the countries that need to be analyzed and managed in each specific government to increase the usage.

\section{Conclusion}

This paper explored what the current level of use of e-government solutions in Russia is and whether or not the use and satisfaction rate for public e-services portals and e-participation platforms is equal within the same institutional framework within a country.

To answer the research questions, the authors conducted desk research and a survey. The paper explored whether or not the Internet penetration rate is high, whether citizens have the right to approach the government remotely, what the level of trust in the government is, the level of usage of public e-services portals and e-participation platforms, the level of computer skills, and overall satisfaction. The findings show that Internet penetration as an opportunity to use e-government tools is rather high $(75,4 \%)$, but the actual level of use of public e-services is low (29\%) and even lower for e-participation (17\%). The use gap between traditional and online channels of interaction with the government is making Russia comparable to other countries. A high Internet penetration rate, extended rights of the citizens to apply to government authorities remotely, and a moderate level of trust in the government belong to the group of factors that positively affect the usage. At the same time, the absence of skills, devices, and needs within some socio-economic groups, plus the lack of a first successful attempt (experience) (for different reasons, including fear of technology, trust in it, psychological factors, etc.) belongs to the group of factors that negatively affect the usage of e-government solutions.

The study confirmed the results of existing literature that also emphasized that "despite the significant amounts of public investment devoted to enhancing e-government over the last ten years, citizens' use of this service is still limited, posing a challenge to national governments" (Pérez-Morote et al., 2020). And the problem of the low usage of e-government solutions is common for many emerging countries, including Russia. The contribution of this study could be measured by:

- the assessment of the current level of use of e-government solutions in Russia (for public e-services portals and e-participation platforms) and the exploration of some of the key factors that influence the use (Internet penetration rate, citizens' rights to approach the government remotely, the level of trust in government, the level of usage of public e-services portals and e-participation platforms, the level of computer skills, and overall satisfaction);

- proving the statement: within the same institutional framework the use and satisfaction rate for public e-services portals and e-participation platforms could differ; the nature of e-government solutions (whether it is a public e-service portal or an e-participation platform) should be considered when governments are developing roll-out programs;

- $\quad$ suggesting three practical recommendations to accelerate the usage of e-government solutions. 
The research has some limitations. As we mentioned in section 3, multiple variables affect the level of use of e-government solutions. This paper considers only some of these, based on the data available. The article represents the first layer of the analysis and does not share some of the more in-depth results of the analysis. For example, the relationship between citizens' experience with "off-line public services" and their use of e-government solutions, which will be the subject of the next article.

\section{Declaration of Competing Interest}

This article is an output of a research project implemented as part of the Basic Research Program at the National Research University Higher School of Economics (HSE University). The research has been executed independently by the authors.

\section{CRediT author statement}

Sergey A. Revyakin: Conceptualization, Methodology, Validation, Formal Analysis, Investigation, Data Curation, Writing - Original Draft; Álvaro da Rocha: Writing - Review \& Editing.

\section{Acknowledgments}

We would like to thank Dr. Irina Mersyanova for arranging the survey and sharing the data. We would like to thank the review team for their encouragement and guidance throughout the review process.

\section{REFERENCES}

1. Al-Adawi, Z., Yousafzai, S. \& Pallister, J. (2000). E-Government. Getting IT Right at the Start. The Health Service Journal, vol. 110, no 5728, pp. 1-10.

2. Al Bastaki, M. (2004). Dubai eGovernment Achievements \& Upcoming Challenges. Available at: https://www.oecd.org/mena/governance/36279733.pdf (accessed: 09 April 2021).

3. Al Nidawy, B.Q.J., Sidek, S. \& Al-Shami, S.A. (2018). Systematic Review of Critical Factors and Their Dimensions Influencing Trust in e-Government for Usage or Willingness to Use by Citizens: Taxonomy, Open Challenges, Motivation and Recommendations. Opcion, vol. 34, no 85 , pp. 2748-2794.

4. Al Nidawy, B.Q., Sidek, S., Al-Shami, S. A. \& Elzamly, A. (2020). E-Government Trust Model (Egov-Trust) that Enhances the Usage of E-Government Services among Users in Iraq. Journal of Theoretical and Applied Information Technology, vol. 98 no 3, pp. 402-418. 
5. Bélanger, F. \& Carter, L. (2008). Trust and Risk in e-Government Adoption. Journal of Strategic Information Systems, vol. 17, no 2, pp. 165-176. Available at: https://doi.org/10.1016/ j.jsis.2007.12.002 (accessed: 09 April 2021).

6. Carter, L. \& Belanger, F. (2004a). Citizen Adoption of Electronic Government Initiatives. Proceedings of the Hawaii International Conference on System Sciences, vol 37(C), pp. 18951904. Available at: https://doi.org/10.1109/hicss.2004.1265306 (accessed: 09 April 2021).

7. Carter, L. \& Belanger, F. (2004b). The Influence of Perceived Characteristics of Innovating on e-Government Adoption. Electronic Journal of E-Government, vol 2, no 1, pp. 11-20. Available at: https://doi.org/10.1504/IJMC.2011.040606 (accessed: 09 April 2021).

8. Dimitrova, D.V.D.V. \& Chen, Y.C.Y.-C. (2006). Profiling the Adopters of E-Government Information and Services: The Influence of Psychological Characteristics, Civic Mindedness, and Information Channels. Social Science Computer Review, vol. 24, no 2, pp. 172-188. Available at: https://doi.org/10.1177/0894439305281517 (accessed: 09 April 2021).

9. Dwivedi, Y.K., Rana, N.P., Janssen, M., Lal, B., Williams, M.D. \& Clement, M. (2017). An Empirical Validation of a Unified Model of Electronic Government Adoption (UMEGA). Vol. 34, pp. 211-230. Available at: https://doi.org/10.1016/j.giq.2017.03.001 (accessed: 09 April 2021).

10. European Commission. (2018). E-Government Activities of Individuals Via Websites. Available at: https://appsso.eurostat.ec.europa.eu/nui/show.do?dataset=isoc_ciegi_ac\&lang=en (accessed: 09 April 2021).

11. Gil-garcia, J.R. \& Pardo, T.A. (2006). Multi-Method Approaches to Digital Government Research: Value Lessons and Implementation Challenges Multi-Method Approaches to Digital Government Research: Value Lessons and Implementation Challenges. May 2014. Available at: https://doi.org/10.1109/HICSS.2006.356 (accessed: 09 April 2021).

12. Janowski, T., Pardo, T.A. \& Davies, J. (2012). Government Information Networks - Mapping Electronic Governance Cases through Public Administration Concepts. Government Information Quarterly, no 29, S1-S10. Available at: https://doi.org/https://doi.org/10.1016/ j.giq.2011.11.003 (accessed: 09 April 2021).

13. Janssen, M. \& Estevez, E. (2013). Lean Government and Platform-Based Governance-Doing More with Less. Government Information Quarterly, no 30 (SUPPL. 1), S1-S8. Available at: https://doi.org/10.1016/j.giq.2012.11.003 (accessed:09 April 2021).

14. Khalil, I., Nadi, A. \& Woods, P. (2010). Success Factors Contributing to eGovernment Adoption in Saudi Arabia 2. EGovernment Adoption Success Factors.

15. Layne, K. \& Lee, J. (2001). Developing Fully Functional e-Government: A Four Stage Model. Government Information Quarterly, vol. 18, no 2, pp. 122-136. Available at: https://doi.org/ https://doi.org/10.1016/S0740-624X(01)00066-1 (accessed: 09 April 2021).

16. Lin, F., Fofanah, S.S. \& Liang, D. (2011). Assessing Citizen Adoption of e-Government Initiatives in Gambia: A Validation of the Technology Acceptance Model in Information Systems Success. Government Information Quarterly, vol. 28, no 2, pp. 271-279. Available at: https:// doi.org/10.1016/j.giq.2010.09.004 (accessed: 09 April 2021).

17. Missingham, R. (2013). Australian Government Publishing Online a Decade on: Has the Promise Been Delivered? 8623. Available at: https://doi.org/10.1080/00048623.2007.10721310 (accessed: 09 April 2021). 
18. Nam, T. (2014). Determining the Type of e-Government Use. Government Information Quarterly, vol. 31, no 2, pp. 211-220. Available at: https://doi.org/10.1016/j.giq.2013.09.006 (accessed: 09 April 2021).

19. Pedersen, K. \& Tjørnehøj, G. (2018). Successful e-Government Transformation: Pressure, Support, Capabilities and the Freedom to Use Them. Electronic Journal of Electronic Government, vol.16, no 2, pp. 168-184.

20. Pérez-Morote, R., Pontones-Rosa, C. \& Núñez-Chicharro, M. (2020). The Effects of e-Government Evaluation, Trust and the Digital Divide in the Levels of e-Government Use in European Countries. Technological Forecasting \& Social Change, no 154(March), 119973. Available at: https://doi.org/10.1016/j.techfore.2020.119973 (accessed: 09 April 2021).

21. Reffat, R.M. (2006). Developing a Successful E-Government. In Proceedings of the Symposium on eGovernment Opportunities and Challenge, IEEE, pp. 1-13.

22. Scholl, H.J. (2002). E-government: A Special Case of ICT-Enabled Business Process Change. The 36th Hawaii International Conference on System Sciences, pp. 1-12.

23. Sipior, J. \& Ward, B. (2009). Bridging the Digital Divide for e-Government Inclusion: A United States Case Study. Asymptotic and Computational Methods in Spatial Statistics, vol. 167, no 3, pp. 137-146.

24. Stephen, H., Norris, D.F. \& Fletcher, P.D. (2003). Electronic Government at the Local Level. Public Performance \& Management Review, vol. 26, no 4, pp. 325-344. Available at: https:// doi.org/10.1177/1530957603252580 (accessed: 09 April 2021).

25. Thompson, D.V., Rust, R.T. \& Rhoda, J. (2005). The Business Value of e-Government for Small Firms. International Journal of Service Industry Management, vol. 16, no 4, pp. 385-407. Available at: https://doi.org/10.1108/09564230510614022 (accessed: 09 April 2021).

26. United Nations. (2018). 2018 E-Government Survey. Available at: https://publicadministration.un.org/Portals/1/Images/E-Government Survey 2018_FINAL for web.pdf (accessed: 09 April 2021).

27. Warkentin, M., Gefen, D., Pavlou, P.A. \& Rose, G.M. (2002). Encouraging Citizen Adoption of e-Government by Building Trust. Electronic Markets, vol. 12, no 3, pp. 157-162. Available at: https://doi.org/10.1080/101967802320245929 (accessed: 09 April 2021).

28. Yildiz, M. (2007). E-Government Research: Reviewing the Literature, Limitations, and Ways Forward. Government Information Quarterly, vol. 24, no 3, pp. 646-665. Available at: https:// doi.org/https://doi.org/10.1016/j.giq.2007.01.002 (accessed: 09 April 2021). 